\title{
EXERGOECONOMIC ANALYSIS OF IHOVBOR GAS POWER PLANT
}

\author{
S. A. Aliu ${ }^{1, *}$ and P. I. Ochornma ${ }^{2}$

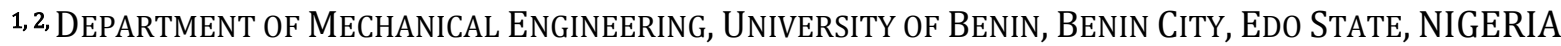 \\ Email addresses. ${ }^{1}$ sufianu.aliu@uniben.edu, ${ }^{2}$ ochornmapromise@gmail.com
}

\begin{abstract}
Exergoeconomic parameters of Ihovbor Gas Power plant were determined in this study. To achieve this, the exergy of each stream, the economic cost of the plant components, the exergetic costs of each stream and the exergoeconomic evaluation of each component were determined. The average exergy efficiency of GTS ONE, TWO, THREE and FOUR were found to be $59.32 \%, 60.83 \%, 59.80 \%$ and $60.38 \%$ respectively and it decreased with increase in ambient temperature. The exergy destruction cost was greatest in the combustor (average of $1596.175 \$ / \mathrm{hr}$ ), the relative cost difference was greatest in the air compressor with an average ratio of 0.36585 , the exergoeconmic factor of the gas turbine was greatest (91.84\%) and the average cost of power generation was found to be $\$ 0.0162 / \mathrm{kWhr}$. Exergoeconomic parameters can be used as tools for energy audit and determining the running costs of power plants and power generation.
\end{abstract}

\section{Key words: Gas Turbine, Exergy, Exergy Destroyed, Efficiency, Cost, Annualized Cost, Exergoeconomic}

\section{INTRODUCTION}

Gas Power Plants are thermal plants that generate either mechanical or electrical power using energized gas. Ihovbor Gas power plant is a $4 \mathrm{x} 112.5 \mathrm{MW}$ (International Organization for Standardization (ISO) 126.1MW) thermal power plant situated in Ihovbor a suburb of Benin City, Edo State, Nigeria and operated by the Niger Delta Power Holding Company (NDPHC) and fueled using natural gas. In managing any energy conversion system, the energy conversion process requires assessment in order to minimize waste of resources and achieve optimal utilization of resources. With the dwindling deposit of fossil fuel and its increasing demand, it becomes necessary to understand the mechanisms which degrade the quality of energy (ability to do work) and energy resources and to develop a systematic approach to improving the systems [1].

One of the tools for assessing power system is efficiency. Researchers today in studying the efficiencies of a system are concerned with the destruction originating in the energy conversion system as a result of change in entropy which the First Law of Thermodynamics cannot determine. Exergy analysis is based on the first and second laws of thermodynamics and makes it possible to characterize the optimal analysis technique on energy systems. It identifies energy levels and adverse thermodynamic processes, and also play an important role in strategic development and provision of instruction set for existing power plants [2-3]. Exergy analysis predicts performances and efficiency of an energy system and its component by quantifying the entropy generation of the system's components [4]. The application of exergy analysis in power plant will help the plant engineer make decisions and possibly optimize plant performance and minimize fuel consumption and reveal inefficient thermodynamic processes [5-7] In exergy analysis, the ambient conditions are the reference point and exergy is possible if the system properties are brought into equilibrium with the ambient properties through reversible processes [8]. According to Dincer and Ratlamwala [9] the reference environment is in stable equilibrium, with all parts at rest relative to one another and no chemical reactions occurring between the environmental components.

The reference environment acts as an infinite system, and is a sink and source for heat and materials. These characteristics of the reference environment must be specified completely and this is commonly done by specifying the temperature, pressure and chemical composition of the reference environment. The results of exergy analyses, are relative to the specified reference environment, which in most applications is 
modelled after the actual local environment and it is a primary tool in best addressing the impact of energy resource utilization on the environment [10].

The following are the importance of exergy and its utilization

1. It is an effective method using the conservation of mass and conservation of energy principles together with the second law of thermodynamics for the design and analysis of energy systems [11].

2. It is a suitable technique for furthering the goal of more efficient energy-resource use, for it enables the locations, types, and true magnitudes of wastes and losses to be determined [11-12].

3. It is an efficient technique revealing whether or not and by how much it is possible to design more efficient energy systems by reducing the inefficiencies in existing systems (Dincer and [1112].

4. It is a key component in obtaining sustainable development [11-12].

Exergy has been a prime tool and its use has been extended to economy by including cost accounting to exergy analysis and exergy streams [9, 13]. The combination of exergetic analysis with its economic implication is known as exergoeconomic analysis. The goal of conducting exergoeconomic analysis of systems is to minimize the cost of exergy [2]. According to [14] exergoeconomic analysis combines the exergy analysis with economic principles and incorporates the associated cost of the thermodynamic inefficiencies in the total product cost of the energy system. Exergoeconomic analysis has become a powerful tool for assessing the performance of energy conversion system for improving overall system efficiency and lowering life cycle costs of a thermodynamic system [15-16]. Exergoeconomics applied to design optimization provide the designer of an energyconversion plant with information not available through conventional energy, or cost analyses, but critical to the design of a cost-effective plant [17]. More also exergoeconomic analysis has been efficiently used as a design tool for the realization of a gas turbine power plant principle [18]. Exergoeconomic analysis estimates the unit cost of products such as electricity and quantifies monetary losses due to irreversibility [4].

For engineering purposes, the results from exergoeconmic analysis are used for improvement of the system, as it is often more cost effective and less time consuming than optimization of the system due to the large uncertainties associated with cost information and normal operational fluctuations of thermodynamic parameters of complex thermal systems [19].

Exergoeconomic analysis as an important tool is used by engineers for:

1. Rational prices assessment/feasibility assessment of plant products based on physical criteria [2021].

2. Optimization of specific process unit variables through improved design concept to minimize the final product cost, i.e. global and local optimization [20-21].

3. Detection of inefficiencies and calculation of their economic effects in operating plants, i.e. plant operation exergoeconomic diagnosis [20].

4. Evaluation and improvement of various design alternatives or operation decisions of the system components and profitability maximization [20-21]

5. Energy audits [20].

Researches on the exergy and exergoeconomic analysis have been carried out.

Kwon et al. [22] in their exergoeconomic analysis of a cogeneration plant found that the cost of products are crucially dependent on the change in the annualized cost of the component whose primary product is the same as the system's product.

Oyedepo et al. [14] in their study of selected gas turbines in Nigeria (Egbim Thermal Power Plant, Ughelli Power PLC, Afam Power Station and AES Barge Gas Turbine Power Plant), discovered that the efficiency of the plants is within the range of 18.22$32.84 \%$. Decrease in ambient temperature results in increase in the plant efficiency. From their exergoeconomic analysis, the low exergoeconomic factor associated with the combustion chamber shows that the cost rate of exergy destruction is the dominant factor influencing the component.

Ogbe et al. [15] carried out a probabilistic exergoecominc analysis of four modeled industrial gas turbine units, two each of 100MW GE Engine and 25MW Hitachi Engine at Transcorp Power Plant in Ughelli, Delta State, Nigeria. From his results, the irreversibility of the gas turbines decreased with an increase in inlet temperature and is consistent with the report by Chand et al. [7] in their analysis of $112.4 \mathrm{MW}$ single shaft in Genting Lanco, Vijayawad at ISO condition.

Mousafarash et al. and Eke et al. [2, 23] from their observation of the exergy efficiencies of thermal plants showed that increase in inlet temperature has negative effect on the exergy efficiency of the cycle and that the heat addition process (combustion chamber/boiler) 
has the maximum rate of exergy destruction due to the chemical reaction, mixture and high temperature. [24] Studied unit 14 of South Tripoli Gas Turbine Power Plant at varying operating load. Their result showed that the average cost per unit exergy net power is equal to $7.1 \$ / \mathrm{GJ}$ at $40 \%$ design loads, and equal to $5.5 \$ / \mathrm{GJ}$ at $60 \%$ design load, and equal to $4 \$ / \mathrm{GJ}$ at full operating load. The exergetic efficiency of the gas turbine increased with increase in operating load.

This research work conducted the exergetic analysis of Ihovbor Gas Power Plant and determined the various cost associated with the components and the exergy streams, and the exergy destroyed using available data from 2014-2017.

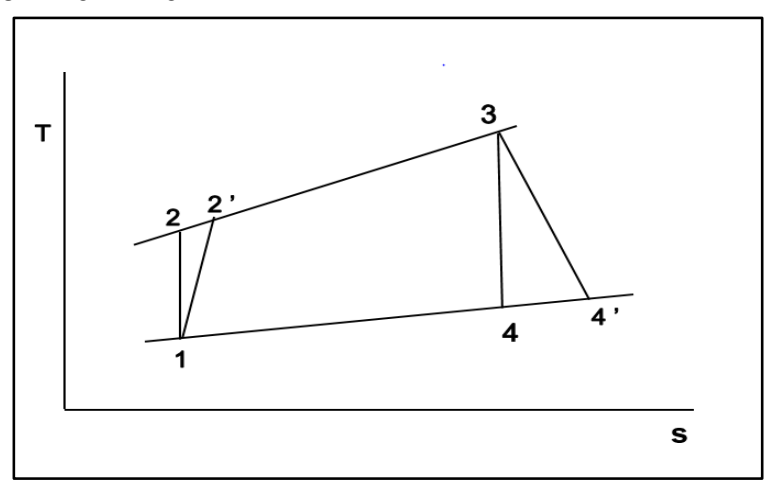

Figure 1: The T-s diagram of a Gas Power Plant

\subsection{Cycle Description}

A gas turbine has typically low efficiency in the range of $20-30 \%$ and operates on Brayton or Joule cycle but it is preferred because of its low capital cost, high flexibility, high reliability without complexity, short delivery time, and fast starting and loading [25-26]. It consists of the air compressor, combustion chamber and the gas turbine and the T-s is illustrated in Figure 1. The air compressor compresses the air isentropically from state 1 to state 2, but due to irreversibility in the air compressor, the air is delivered at state 2' thus generating entropy. The compressed air is heated from state $2 / 2^{\prime}$ at constant pressure to state 3 and the high temperature accompanying heat addition also generates entropy. The energy in the flue gas is extracted by expanding the flue gas isentropically from state 3 to state 4 in the gas turbine but due to irreversibility in the gas turbine it is expanded to state 4' and this also generates entropy. This entropy generation can be reduced by minimizing the irreversibilities such as friction, turbulence, and nonquasi-equilibrium processes [27].

\section{METHODOLOGY}

The four procedure proposed by [28] will be followed in this study. These steps are:
A. Exergy Analysis

B. Economic Analysis of each of the plant component,

C. Estimation of exergetic costs associated with each flow and

D. Exergoeconomic evaluation of each system component.

\subsection{Exergy Analysis}

The exergy stream of any thermo-mechanical system has thermal, pressure and chemical components and entropy is generated due to irreversibilities.

The thermal exergy of the plant at any point $\mathrm{k}$ is given as

$$
E^{T}=\mathrm{mC}_{\mathrm{P}}\left[\left(\mathrm{T}_{\mathrm{k}}-\mathrm{T}_{\mathrm{ref}}\right)-\mathrm{T}_{\mathrm{ref}} \mathrm{In} \frac{\mathrm{T}_{\mathrm{k}}}{\mathrm{T}_{\mathrm{ref}}}\right]
$$

where $E^{T}$ is thermal exergy in MW, $m$ is the mass flow rate of the working fluid in $\mathrm{kg} / \mathrm{s}, \mathrm{C}_{\mathrm{p}}$ is the specific heat capacity of the fluid in $\mathrm{kJ} / \mathrm{kgK} T_{\text {ref }}$ is the ambient temperature and $T_{k}$ is the temperature at point $\mathrm{k}$. From figure 1 , point $\mathrm{k}$ are points $1,2,3,4$ respectively. Temperature is measured in Kelvin $\mathrm{K}$ where

$$
\begin{aligned}
\mathrm{C}_{\mathrm{Pa}}=1.04841 & -\left(\frac{3.8371 \mathrm{~T}}{10^{4}}\right)+\left(\frac{9.4537 \mathrm{~T}^{2}}{10^{7}}\right) \\
& -\left(\frac{5.49031 \mathrm{~T}^{3}}{10^{10}}\right)+\left(\frac{7.9298 \mathrm{~T}^{4}}{10^{4}}\right)
\end{aligned}
$$

where $\mathrm{T}$ is the temperature measured in Kelvin $\mathrm{K}$ The Pressure exergy of the plant at any point is given as

$$
E^{P}=\mathrm{mRT}_{\text {ref }} \operatorname{In} \frac{\mathrm{P}_{\mathrm{k}}}{\mathrm{P}_{\mathrm{ref}}}
$$

where $E^{p}$ is pressure exergy in $\mathrm{MW}, R$ is the gas constant in $\mathrm{kJ} / \mathrm{kgK}, P_{r e f}$ is the ambient pressure and $P_{k}$ is the pressure at point $\mathrm{k}$. Pressure is measured in bar.

For fossil fuel with chemical formula $\mathrm{C}_{\mathrm{a}} \mathrm{H}_{\mathrm{b}}$; the chemical exergy is given as

$$
E^{C H E}=\mathrm{m}_{\mathrm{f}} \times\left(1.033+0.0169 \frac{\mathrm{b}}{\mathrm{a}}-\frac{0.0698}{\mathrm{a}}\right)
$$

where $\mathrm{m}_{\mathrm{f}}$ is mass flow rate of the fuel

The entropy, $\mathrm{S}$ of the plant at any point $\mathrm{k}$ is given as

$$
\mathrm{S}_{\mathrm{k}}=\mathrm{m}\left[\mathrm{C}_{\mathrm{p}} \operatorname{In} \frac{\mathrm{T}_{\mathrm{k}}}{\mathrm{T}_{\mathrm{ref}}}-\mathrm{RIn} \frac{\mathrm{P}_{\mathrm{k}}}{\mathrm{P}_{\mathrm{ref}}}\right]
$$

For any component of the system the total exergy is given as :

$$
\begin{gathered}
\mathrm{E}^{\mathrm{CHE}}+\sum\left(\mathrm{E}_{\mathrm{o}}^{\mathrm{T}}-\mathrm{E}_{\mathrm{i}}^{\mathrm{T}}\right)+\sum\left(\mathrm{E}_{\mathrm{o}}^{\mathrm{P}}-\mathrm{E}_{\mathrm{i}}^{\mathrm{P}}\right)+\mathrm{T}_{\mathrm{ref}} \sum\left(\mathrm{S}_{\mathrm{o}}-\mathrm{S}_{\mathrm{i}}\right) \\
+\mathrm{Q}_{\mathrm{CC}}+\mathrm{W}=0
\end{gathered}
$$

where subscript $o$ and $i$ are the sum values at entry and exit of the component respectively.

And the exergy destroyed, $E_{D}$ the component due to change in entropy of the process is given by equation

$$
\mathrm{E}_{\mathrm{D}}=\mathrm{T}_{\mathrm{ref}} \sum\left(\mathrm{S}_{\mathrm{o}}-\mathrm{S}_{\mathrm{i}}\right)
$$


The efficiencies of the components and the plant are given by equations (8) - (11)

Compressor:

$$
\eta_{A C}=1-\frac{E_{D, A C}}{E^{W, A C}}
$$

Combustion chamber:

$$
\eta_{\mathrm{CC}}=1-\frac{E_{\mathrm{D}, \mathrm{CC}}}{\mathrm{E}^{\mathrm{CHE}}}
$$

Gas turbine:

$$
\eta_{\mathrm{GT}}=1-\frac{\mathrm{E}_{\mathrm{D}, \mathrm{GT}}}{\mathrm{E}^{\mathrm{W}, \mathrm{GT}}}
$$

where $E_{D}, A C, E_{D}, C c, E_{D, G T}$ are the exergy destroyed in the air compressor, combustion chamber and gas turbine respectively while $\mathrm{E}^{\mathrm{W}, \mathrm{AC}}$ and $\mathrm{E}^{\mathrm{W}, \mathrm{GT}}$ are the work done on the air compressor and the gross work done by the gas turbine.

Overall plant:

$$
\eta_{\text {PLANT }}=1-\frac{\sum E_{D}}{E^{C H E}}
$$

Exergy destruction rate, is given by equation (12)

$$
\varepsilon_{\mathrm{d}}=\frac{\sum \mathrm{E}_{\mathrm{D}}}{E^{C H E}}
$$

where, $\sum E_{D}=E_{D, A C}+E_{D, C C}+E_{D, G T}$

\subsection{Economic Analysis of the Plant}

The economic analysis of the plant shows the investment, operation and maintenance cost of the plant and are necessary for analyzing the exergy cost of the streams in the system.

Annualization cost method proposed by Moran [29] was used in carrying out the analysis. Annualization cost of the equipment ( $\dot{\mathrm{C}}) \$ / \mathrm{yr}$ is determined in accordance with [30-31]

$$
\dot{\mathrm{C}}=\mathrm{PW} \times \mathrm{CRF}
$$

where PW is the Present Worth and CRF the cost recovery factor.

The PW of the plant's component is proportional to Cost of the equipment known as Purchase Equipment Cost (PEC), the Salvage cost SV and the Present Worth Factor PWF

$$
\mathrm{PW}=\mathrm{PEC} \times(-\mathrm{SV}) \mathrm{PWF}
$$

PEC of the different component as stated by [32]. For air compressor:

$$
\mathrm{PEC}=\left[\frac{71.1 \mathrm{~m}_{\mathrm{a}}}{0.9-\eta_{\mathrm{AC}}}\right]\left[\frac{\mathrm{P}_{2}}{\mathrm{P}_{1}}\right] \operatorname{Ln}\left[\frac{\mathrm{P}_{2}}{\mathrm{P}_{1}}\right]
$$

Efficiency of air compressor $\eta_{A C}$ is taken as $89.4 \%$ For the combustion chamber:

$$
\begin{aligned}
& P E C=\left[\frac{46.08 \mathrm{~m}_{\mathrm{a}}}{0.995-\mathrm{P}_{3} / \mathrm{P}_{2}}\right][1 \\
& \left.+\exp \left(0.018 \mathrm{~T}_{3}-26.4\right)\right]
\end{aligned}
$$

For gas turbine:

$$
\begin{aligned}
P E C=\left[\frac{479.34 \mathrm{~m}_{\mathrm{g}}}{0.92-\eta_{\mathrm{GT}}}\right] \operatorname{Ln}\left[\frac{\mathrm{P}_{3}}{\mathrm{P}_{4}}\right][1 \\
\left.+\exp \left(0.036 \mathrm{~T}_{3}-54.4\right)\right]
\end{aligned}
$$

Efficiency of gas turbine $\eta_{\text {GT }}$ taken as $87.8 \%$

From figure $1, \mathrm{P}_{1}, \mathrm{P}_{2}, \mathrm{P}_{3}, \mathrm{P}_{4}$ are the pressures at point $1,2,3,4$ respectively, $T_{3}$ is the temperature at point 3 while $m_{a}$ and $m_{g}$ are the mass flow rates of air and flue gas respectively.

$$
\begin{aligned}
\mathrm{CRF} & =\frac{\mathrm{i}}{1-(1+\mathrm{i})^{-\mathrm{N}}} \\
\mathrm{PWF} & =(1+\mathrm{i})^{-\mathrm{N}}
\end{aligned}
$$

Capital cost $\mathrm{Z}$ in $\$ /$ sec for each component is given as

$$
Z=\frac{\emptyset_{\mathrm{K}} \times \dot{\mathrm{C}}}{3600 \times \mathrm{n}}
$$

For the Analysis of the plant, the following assumptions/values were used

Salvage cost SV $=10 \%$ of PEC

Interest $(\mathrm{i})=17 \%$

Years of plant $(\mathrm{N})=4 \mathrm{yrs}(2014-2017)$

Maintenance factor $\emptyset_{\mathrm{k}}=1.06$

Operating hour per year $(\mathrm{n})=8472$

\subsection{The Exergy Cost of Each Stream}

Exergy costing is based on a principle that exergy is the only rational basis for assigning monetary values to the interactions an energy system experiences with its surroundings and to the thermodynamic inefficiencies within the system as the exclusive use of mass, energy or entropy results in misleading conclusions [17].



Figure 2: Gas Turbine with Encoding for Exergy Cost Analysis

In analyzing the exergy cost of the simple gas power plant having air compressor, combustion chamber and gas turbine the code/numberings in figure 2 is used. The Specific-Cost Exergy Costing (SPECO) method proposed by Lazzaretto and Tsatsaronis [33] was used for all the components of the system to construct a set of nonlinear algebraic equations. 
The formulations of the equations are shown in equations (22) - (24) for air compressor, combustion chamber and gas turbine respectively.

$$
\begin{aligned}
& \mathrm{C}_{2}=\mathrm{C}_{1}+\mathrm{C}_{6}+\mathrm{Z}_{\mathrm{AC}} \\
& \mathrm{C}_{3}=\mathrm{C}+\mathrm{C}_{5}+\mathrm{Z}_{\mathrm{CC}} \\
& \mathrm{C}_{4}+\mathrm{C}_{6}+\mathrm{C}_{7}=\mathrm{C}_{3}+\mathrm{Z}_{\mathrm{GT}}
\end{aligned}
$$

Auxiliary equations (25) and (26) were also used

$$
\begin{aligned}
& \frac{\mathrm{C}_{3}}{\mathrm{E}_{3}}=\frac{\mathrm{C}_{4}}{\mathrm{E}_{4}} \\
& \frac{\mathrm{C}_{6}}{\mathrm{~W}_{\mathrm{AC}}}=\frac{\mathrm{C}_{7}}{\mathrm{~W}_{\text {net }}}
\end{aligned}
$$

where $\mathrm{E}^{\mathrm{W}}$, NET is the work-net of the plant.

The cost of fuel $\dot{C}_{5}$ for power is taken as $\$ 3.16$ per GJ (\$3.34 per MMBTU)

$$
\mathrm{C}_{5}=\dot{\mathrm{C}}_{5} \times \mathrm{E}^{C H E}
$$

where $C$ is the specific annualized cost in $\$ /$ sec

\subsection{Exergoeconomic Cost}

Average cost per unit fuel of exergy $\mathrm{C}_{\mathrm{FE}}$ for each component

$$
c_{F E}=\frac{\mathrm{C}_{\mathrm{F}}}{\mathrm{E}_{\mathrm{F}}}
$$

Average cost per unit product of exergy $\mathrm{C}_{\mathrm{PE}}$ for each component

$$
c_{P E}=\frac{\mathrm{C}_{\mathrm{P}}}{\mathrm{E}_{\mathrm{P}}}
$$

Cost of exergy destruction $C_{D}$

$$
\mathrm{C}_{\mathrm{D}}=C_{F E} \times \mathrm{E}_{\mathrm{D}}
$$

where $E_{F}$ and $E_{P}$ are the exergy fuel and exergy product for each component while $C_{F}$ and $C_{P}$ is the cost of the fuel and product respectively.

The inlets to each component are the fuel for the component while outlets from the components are the products for the component.

\subsubsection{Relative Cost Difference $r_{k}$}

Relative cost difference $r_{k}$ shows the rate of increase of the cost of exergy in each component. This cost increase between cost of fuel $C_{F E}$ and cost of product $C_{P E}$ is caused by the cost of exergy destruction and the investment related cost (Capital cost $\mathrm{Z}$ ) as the relative cost difference $r_{k}$ shows [17].

$$
r k=\frac{C_{P}-C_{F}}{C_{F}}
$$

\subsubsection{Exergeconomic Factor $f_{k}$}

The exergoeconomic factor $f_{K}$ compares the two cost sources contributing to the cost increase between $C_{F}$ and $C_{P}$ and shows the contribution of the investmentrelated cost to the sum of cost of exergy destruction and investment-related cost [17].

$$
f_{k}=\frac{Z}{Z+C_{D}}
$$

\section{RESULTS AND DISSCUSSION}

\subsection{Exergy Analysis}

The data for the exergy analysis which is the average performance data of the plant based on inlet air temperature was gotten using Microsoft Excel sheet. The data represents the calculated performance of the plant installed at Ihovbor which is a General Electric 9E Frame Gas Turbine (PP.9171E) while the data for the economic, exergy cost and exergoeconomic cost is the average performance data of the plant from January 2014 to May 2017.

The results of the exergy analysis shown in Figs 3, 4, 5 and 6 showed that the component with the lowest efficiency is the combustion chamber as its average efficiency is $64.03 \%, 64.81 \%, 64.37 \%$ and $64.67 \%$ for GT ONE, GT TWO, GT THREE and GT FOUR respectively and this is caused by the high irreversibility accompanying combustion and mixing and this gives room for improvement of combustors for resources utilization. [2,23,35]. The plant has an average efficiency of over $98 \%$ in the gas turbine which is the highest of all the components while the air compressor has efficiencies of $89.85 \%, 91.37 \%, 89.83 \%$ and 90.522\% for GT ONE, GT TWO, GT THREE and GT FOUR respectively.

Generally, the average efficiencies of Ihovor Gas Power Plant are 59.32\%, 60.83\%, 59.80\% and $60.38 \%$ for GT ONE, GT TWO, GT THREE and GT FOUR respectively. From the plant linear trend line the efficiency of the plant generally decreased with increase in temperature as increase in inlet air temperature leads to increase in irreversibility thus increasing exergy destruction rate $[2,14,15,34,35]$.

\subsection{Economic, Exergy Cost and Exergoeconomic Analysis of the Plant}

From the economic analysis of the plant as shown in Table 1, the air compressor PEC is greatest with above $\$ 21 \mathrm{M}$ and this depends on the mass of air compressed. The combustion chamber PEC is lowest (\$0.32M) and it depends on the mass of air and the pressure loss during combustion. The PEC of the Gas Turbine is $\$ 13 \mathrm{M}$ and this depends on the mass of the flue gas.

Table 2 shows the exergy cost of each of the streams at the price of $\$ 3.16$ per GJ (\$3.34 per MMBTU the exergy with greatest cost is at point 3 and this is due to high thermal exergy accompanying heat addition. 


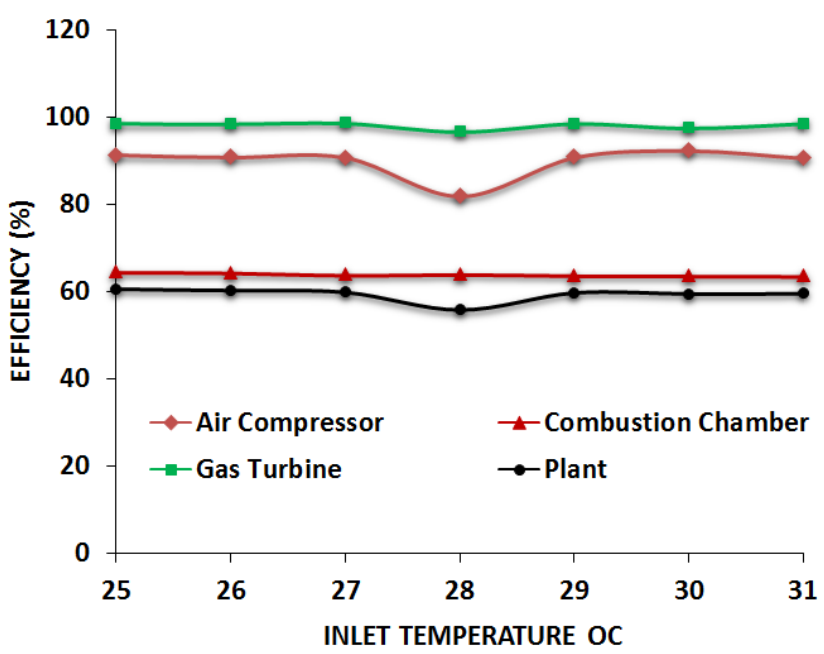

Figure 3: Exergy Efficiencies of Gas Turbine 1



Figure 5: Exergy Efficiencies of Gas Turbine 3

The exergy cost of the streams were found to be dependent on the annualized cost of the plant components (Kwon et al., 2001). From the result of the exergy cost, the price of electricity (product) is $\$ 0.016$, $\$ 0.0162$ and $\$ 0.0163$ and $\$ 0.0164$ per $\mathrm{kWhr}$ and is an average of $\$ 0.0162$ per $\mathrm{kWhr}$ ( $\$ 4.60$ per GJ) generated by the power plant which is almost equivalent to the price of final exergy of [24] at 100\% design load.

From the results in Table 3 , the cost of exergy destruction is greatest in the combustion chamber with an average of $\$ 1596.186$ per hour followed by the air compressor and the least is the gas turbine with

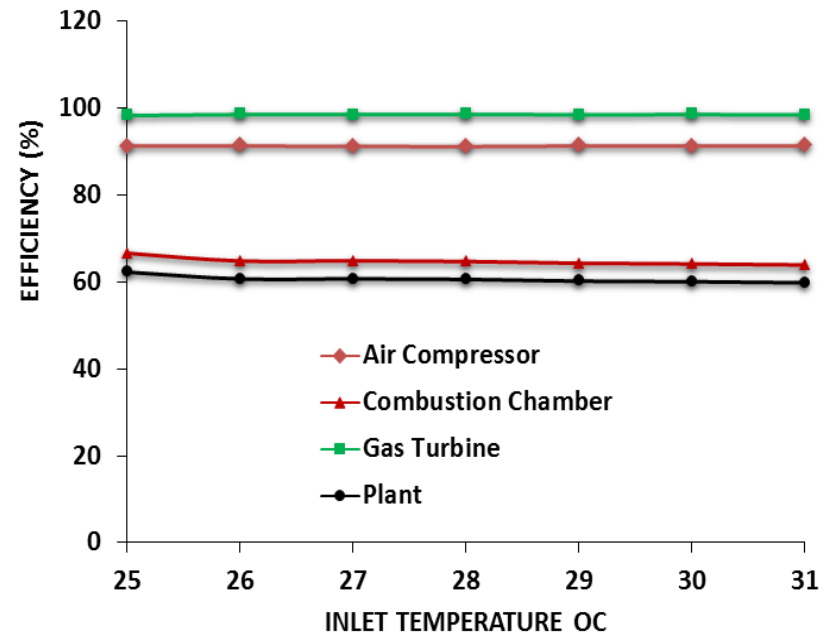

Figure 4: Exergy Efficiencies of Gas Turbine 2

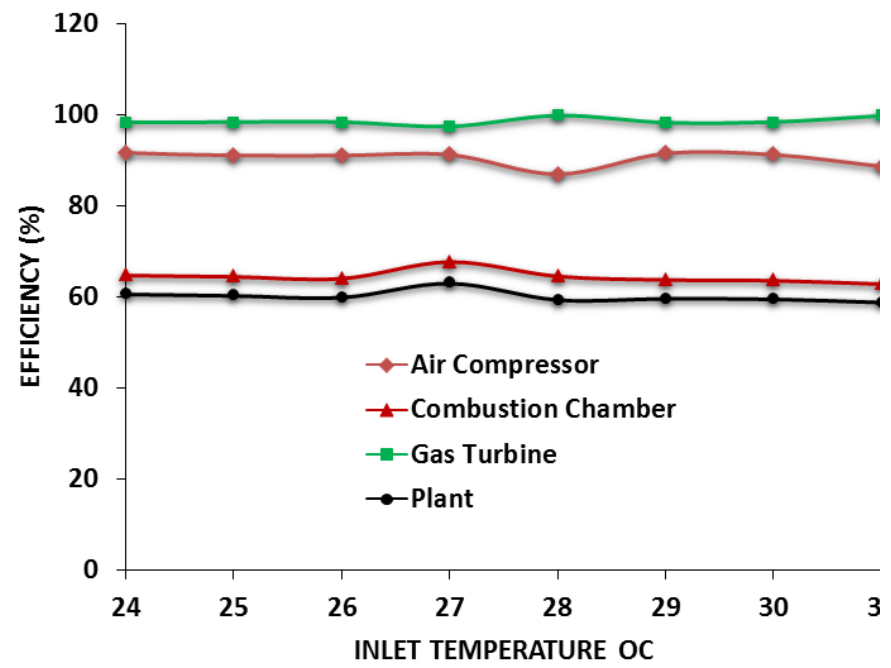

Figure 6: Exergy Efficiencies of Gas Turbine 4

average values of $\$ 164.333$ per hour and $\$ 44.576$ per hour respectively. From the relative cost difference, the air compressor is the most affected by the sum of cost of exergy destruction and investment related cost while the least is the combustion chamber. The cost of investment played the most significant role in increasing cost of exergy in the gas turbine while the cost of exergy destruction plays the most significant role in the increase of cost of exergy in the combustion chamber. Thus, increase in capital investment especially in gas turbine inlet temperature will improve its efficiency [14].

Table 1: Economic Analysis of the Plant

\begin{tabular}{|c|c|c|c|c|c|c|c|c|c|}
\hline GT & \multicolumn{3}{|c|}{ PURCHASE EQUIPMENT COST (\$) } & \multicolumn{3}{|c|}{ ANNUALIZATION COST (\$/YR) } & \multicolumn{3}{|c|}{ CAPITAL COST Z $(\$ /$ sec $)$} \\
\hline & $\mathrm{AC}^{*} 10^{6}$ & $\mathrm{CC}^{*} 10^{6}$ & $\mathrm{GT}^{*} 10^{6}$ & $\mathrm{AC}^{*} 10^{6}$ & $\mathrm{CC}^{*} 10^{6}$ & $\mathrm{GT}^{*} 10^{6}$ & $\mathrm{AC}$ & $\mathrm{CC}$ & GT \\
\hline 1 & 21.517 & 0.3275 & 13.007 & 6.419 & 0.098 & 3.88 & 0.223 & 0.0034 & 0.1349 \\
\hline 2 & 22.997 & 0.3327 & 13.211 & 6.86 & 0.099 & 3.941 & 0.238 & 0.00345 & 0.137 \\
\hline 3 & 21.836 & 0.3203 & 13.237 & 6.514 & 0.096 & 3.949 & 0.226 & 0.00332 & 0.1372 \\
\hline 4 & 24.756 & 0.3633 & 13.888 & 7.385 & 0.108 & 4.143 & 0.257 & 0.00377 & 0.144 \\
\hline
\end{tabular}


Table 2A: Exergy Cost of each Stream

\begin{tabular}{|c|c|c|c|c|c|c|}
\hline \multirow[b]{2}{*}{ POINT } & \multicolumn{3}{|c|}{ GT ONE } & \multicolumn{3}{|c|}{ GT TWO } \\
\hline & $\mathrm{C}(\$ / \mathrm{HR})$ & $\mathrm{C}(\$ / G \mathrm{~J})$ & $\mathrm{C}(\$ / \mathrm{KWHR})$ & $\mathrm{C}(\$ / \mathrm{HR})$ & $\mathrm{C}(\$ / \mathrm{GJ})$ & $\mathrm{C}(\$ / \mathrm{KWHR})$ \\
\hline 1 & 0 & 0 & 0 & 0 & 0 & 0 \\
\hline 2 & 2403.36 & 6.115 & 0.022 & 2460.05 & 6.312 & 0.0227 \\
\hline 3 & 5966.12 & 3.94 & 0.0142 & 5986.52 & 3.983 & 0.0143 \\
\hline 4 & 2946.27 & 3.94 & 0.0142 & 2934.71 & 3.983 & 0.0143 \\
\hline 5 & 3552.7 & 3.16 & 0.0114 & 3516.31 & 3.16 & 0.0114 \\
\hline 6 & 1741.99 & 4.432 & 0.016 & 1757.55 & 4.509 & 0.0162 \\
\hline 7 & 1655.42 & 4.432 & 0.016 & 1697.83 & 4.509 & 0.0162 \\
\hline \multicolumn{7}{|c|}{ Table 2B: Exergy Cost of each Stream } \\
\hline & \multicolumn{3}{|c|}{ GT THREE } & \multicolumn{3}{|c|}{ GT FOUR } \\
\hline POINT & $\mathrm{C}(\$ / \mathrm{HR})$ & $\mathrm{C}(\$ / \mathrm{GJ})$ & $\mathrm{C}(\$ / \mathrm{KWHR})$ & $\mathrm{C}(\$ / \mathrm{HR})$ & $\mathrm{C}(\$ / \mathrm{GJ})$ & $\mathrm{C}(\$ / \mathrm{KWHR})$ \\
\hline 1 & 0 & 0 & 0 & 0 & 0 & 0 \\
\hline 2 & 2322.52 & 5.808 & 0.0209 & 2608.61 & 6.372 & 0.0229 \\
\hline 3 & 6137.88 & 3.995 & 0.0144 & 6262.59 & 4.023 & 0.0145 \\
\hline 4 & 3083.03 & 3.995 & 0.0144 & 3067.83 & 4.023 & 0.0145 \\
\hline 5 & 3647.51 & 3.16 & 0.0114 & 3643.04 & 3.16 & 0.0114 \\
\hline 6 & 1809.74 & 4.526 & 0.0163 & 1862.72 & 4.55 & 0.0164 \\
\hline 7 & 1651.74 & 4.527 & 0.0163 & 1750.48 & 4.55 & 0.0164 \\
\hline
\end{tabular}

Table 3A: Exergoeconomic Cost

\begin{tabular}{|c|c|c|c|c|c|c|}
\hline \multirow[b]{2}{*}{ EXOGERMIC PARAMETER } & \multirow[b]{2}{*}{$\mathrm{AC}$} & \multicolumn{2}{|c|}{ GT ONE } & \multicolumn{3}{|c|}{ GT TWO } \\
\hline & & $\mathrm{CC}$ & GT & $\mathrm{AC}$ & $\mathrm{CC}$ & GT \\
\hline$C_{f E}(\$ / \mathrm{GJ})$ & 4.432 & 3.9254 & 3.9399 & 4.5095 & 3.9776 & 3.9828 \\
\hline$C_{p E}(\$ / G \mathrm{~J})$ & 6.115 & 3.9399 & 4.104 & 6.312 & 3.9828 & 4.1609 \\
\hline $\mathrm{E}_{\mathrm{D}}(\mathrm{MW})$ & 10.81 & 110.88 & 2.0873 & 9.345 & 108.8 & 2.9441 \\
\hline $\mathrm{C}_{\mathrm{D}}(\$ / \mathrm{h})$ & 172.5 & 1566.9 & 29.606 & 151.71 & 1558 & 42.213 \\
\hline $\mathrm{Z}(\$ / \mathrm{h})$ & 803.1 & 12.223 & 485.47 & 858.32 & 12.417 & 493.07 \\
\hline$C_{D}+Z(\$ / h)$ & 975.6 & 1579.1 & 515.08 & 1010 & 1570.4 & 535.28 \\
\hline$F_{K}(\%)$ & 82.32 & 0.774 & 94.252 & 84.98 & 0.7907 & 92.114 \\
\hline$R_{K}$ & 0.38 & 0.0037 & 0.0417 & 0.3997 & 0.0013 & 0.0447 \\
\hline \multicolumn{7}{|c|}{ Table 3B: Exergoeconomic Cost } \\
\hline & \multicolumn{3}{|c|}{ GT THREE } & \multicolumn{3}{|c|}{ GT FOUR } \\
\hline EXOGERMIC PARAMETER & AC & $\mathrm{CC}$ & GT & AC & $\mathrm{CC}$ & GT \\
\hline$C_{f E}(\$ / G \mathrm{~J})$ & 4.5257 & 3.8413 & 3.9949 & 4.5501 & 4.0022 & 4.0232 \\
\hline$C_{p E}(\$ / \mathrm{GJ})$ & 5.808 & 3.9949 & 4.1659 & 6.3721 & 4.0232 & 4.1998 \\
\hline $\mathrm{E}_{\mathrm{D}}(\mathrm{MW})$ & 10.797 & 117.31 & 3.4112 & 9.6 & 113.66 & 3.965 \\
\hline $\mathrm{C}_{\mathrm{D}}(\$ / \mathrm{h})$ & 175.91 & 1622.2 & 49.059 & 157.25 & 1637.6 & 57.427 \\
\hline $\mathrm{Z}(\$ / \mathrm{h})$ & 815.01 & 11.954 & 494.06 & 924 & 13.558 & 518.36 \\
\hline $\mathrm{C}_{\mathrm{D}}+\mathrm{Z}(\$ / \mathrm{h})$ & 990.92 & 1634.2 & 543.11 & 1081.2 & 1651.2 & 575.79 \\
\hline$F_{K}(\%)$ & 82.248 & 0.7315 & 90.967 & 85.457 & 0.8211 & 90.026 \\
\hline$R_{K}$ & 0.2833 & 0.04 & 0.0428 & 0.4004 & 0.0052 & 0.0439 \\
\hline
\end{tabular}




\section{CONCLUSIONS}

The exergy analysis of Ihovbor gas power plant was done in this study and the cost implication of the result of the exergy analysis was determined.

The result of the exergy analysis showed that the gas turbine has the highest exergy efficiency while the combustion chamber has the lowest exergy efficiency. The low exergy efficiency of the combustion chamber was caused by the large thermal exergy lost during combustion reaction. The result also showed that increase in temperature leads to decrease in plant exergy efficiency. The plant average efficiencies were found to be $59.32 \%, 60.83 \%, 59.80 \%$ and $60.38 \%$ for GT ONE, GT TWO, GT THREE and GT FOUR respectively.

The economic cost of the plant showed that the air compressor PEC was greatest at above $\$ 21 \mathrm{M}$, the gas turbine above $\$ 13 \mathrm{M}$, while that of the combustion chamber was least with $\$ 0.32 \mathrm{M}$. The exergy cost analysis showed that the cost of power generation was at an average of $\$ 0.0162$ per $\mathrm{kWhr} / \$ 4.5045$ per GJ generated by the power plant. The exergoeconomic analysis of the plant showed that the sum cost of investment and exergy destroyed influenced the increase in cost of exergy of the air compressor the most and the combustion chamber the least.

The low exergoeconomic factor of the combustion chamber showed that the cost of exergy was the defining factor in its increase of exergy while investment cost is the significant factor increasing the cost of exergy in the air compressor and the gas turbine.

Exergoeconmic parameters can be used as a tool for carrying out energy audit, managing the cost of power generation and determining the running cost of power plants.

\section{REFERENCES}

[1]. Lebele-Alawa B. T., Asuo J. M. "Exergy Analysis of Kolocreek Gas-Turbine Plant", Canadian Journal on Mechanical Sciences \& Engineering, Vol. 2 No. 8, pp. 172-184, 2011.

[2]. Mousafarash A., Ameri M. "Exergy and ExergoEconomic Based Analysis of a Gas Turbine Power Generation System", Journal of Power Technologies, Vol 93, pp. 44-51, 2013.

[3]. Osueke C. O, Onokwai A. O., Adeoye A. 0. "Energy and Exergy Analysis of a $75 \mathrm{mw}$ Steam Power Plant in Sapele (Nigeria)", International Journal of Innovative Research in Advanced Engineering
(IJIRAE), Issue 6 vol.2 ISSN: 2349-2163, pp. 169179, 2015.

[4]. Gorji-Bandpy M., Ebrahimian V. "Exergoeconomic analysis of gas turbine power plants", International Energy Journal, Vol. 7, pp. 35-41, 2006.

[5]. Jin H.H, Ishida M. M, Kobayashi M. M, Nunokawa M. M. "Exergy Evaluation of Two Current Advanced Power Plants: Supercritical Steam Turbine and Combined Cycle", ASME. Journal of Energy Resources Technology, Vol. 119, pp. 250256. doi:10.1115/1.2794998, 1997.

[6]. Ameri M., Ahmadi P., Hamidi P. “Energy, Exergy And Exergoeconomic Analysis Of A Steam Power Plant:A Case Study", International Journal of Energy Research, vol. 33, pp. 499-512, 2009.

[7]. Chand V.T., Sankar R. B., Chowdary J. R. "Exergy Analysis of Gas Turbine Power Plant", International Journal of Engineering Trends and Technology (IJETT), Volume 4, Issue 9, ISSN: 2231-5381, pp. 3991-3393, 2013.

[8]. Gundersen T. "An Introduction to The Concept of Exergy and Energy Quality", Energy and Process Engineering,, pp. 1-25, 2009.

[9]. Dincer I., Ratlamwala T.A.H. "Importance of Exergy for Analysis, Improvement, Design, And Assessment", WIREs Energy and Environment, Vol. 2, pp. 335-349 doi:10.1002/wene.63, 2012.

[10]. Moran, M. J. and Sciubba, E. "Exergy Analysis: Principles and Practice", Engineering for Gas Turbines and Power, Vol. 116, pp.285-302,1994.

[11]. Dincer I., Cengel Y. "Energy, Entropy and Exergy Concepts and Their Roles in Thermal Engineering", Entropy, 3(3); pp. 116-149 2001.

[12]. Kanoğlu M. Cengel Y. A. Dincer I. Efficiency Evaluation of Energy Systems, Springer, New York, 2012

[13]. Pousa A. C., Pereira E.M.D., Arrieta F.R.P, "Exergoeconomic Analysis and Optimization of A Combined-Cycle Cogeneration System", 20th International Congress of Mechanical Engineering Gramado, RS, Brazil, November 15202009.

[14]. Oyedepo, S. O., Fagbenle, R. O., Adefila, S. S., \& Alam, M. M. "Exergy Costing Analysis and Performance Evaluation of Selected Gas Turbine Power Plants", Cogent Engineering, Vol. 2., pp. 121. 2015.

[15]. Ogbe P.O., Anosike N.B., Okonkwo U.C. "Probabilistic Exergoeconomic Analysis of Transcorp Power Plant, Ughelli", Energy and Power Engineering, 9, ISSN Online: 19473818 ISSN Print: 1949 243X, pp. 588-613, 2017. 
[16]. Gupta M., Kumar R. "Exergoeconomic Analysis of a Boiler for a Coal Fired Thermal Power Plant", American Journal of Mechanical Engineering, Vol. 2, No. 5, pp. 143-146, 2014.

[17]. Tsatsaronis G. "Application of Thermoeconomics to the Design and Synthesis of Energy Plants", Energy, Energy System Analysis, and Optimization Vol.2, pp. 160-172, 2007.

[18]. Attala L., Facchini B., Ferrara G. "Thermoeconomic Optimization Method As Design Tool In Gas-Steam Combined Plant Realization", Energy Conversion and Management, Volume 42, Issue 18; 2001, pp. 2163-2172,

[19]. Leonardo S. V, Donatelli J. L., Manuel E. C. "Exergoeconomic Improvement: An Alternative to Conventional Mathematical Optimization of Complex Thermal Systems", 6th World Congress on Structural and Multidisciplinary Optimization Rio de Janeiro, Brazil 30th May 3rd June, 2005

[20]. Valero A., Cuadra C.T. "Thermoeconomic Analysis", Exergy, Energy System Analysis and Optimization - Vol. II 2009, pp.1-35

[21]. Gaggioli R. A., Wepfer W. J. "Exergy Economics: Cost Accounting Applications", Energy, Volume 5, Issues 8-9; pp. 823-837 1980.

[22]. Kwon Y, Kwak H, Si-Doek Oh, "Exergoeconomic Analysis Of Gas Turbine Cogeneration Systems", Exergy, An International Journal, Volume 1, Issue 1, 2001, pp. 31-40

[23]. Eke M. N., Onyejekwe D.C., Iloeje O. C., Ezekwe C. I., Akpan P.U. "Energy and Exergy Evaluation of a 220mw Thermal Power Plant", Nigerian Journal of Technology Vol. 37, No. 1, pp. 115 - 123; 2018.

[24]. Fellah G. M., Mgherbi F. A., Aboghres S. M. "Exergoeconomic Analysis for Unit Gt14 of South Tripoli Gas Turbine Power Plant", Jordan Journal of Mechanical and Industrial Engineering, Volume 4, Number 4, 2010, pp. 507 - 516.

[25]. Eastop T. D. McConkey A.; Applied Thermodynamics for Engineering Technicians 5th Edition; Pearson Education Limited, Edinburgh Gate, 1993.

[26]. Sulaiman M. A., Waheed M. A., Adesope W. A., Noike A. 'Techno-Economic Investigation of
Different Alternatives of Improving Simple Gas Turbine Integration Options", Nigerian Journal of TechnologyVol. 36, No. 3, pp. 849 - 857; 2017.

[27]. Cengel Y. A. and Boles M. A.: Thermodynamics: An Engineering Approach 7th Edition; Mcgraw Hill, New York, 2011

[28]. Tsatsaronis, G. "Thermoeconomic Analysis and Optimization of Energy Systems", Progress in Energy and Combustion Science Vol.19, Issue 3, pp. $227-257,1993$.

[29]. Moran, M. J., Availability Analysis: A Guide to Efficient Energy Use, Prentice -Hall, Englewood Clifs, New Jersey, 1982

[30]. Gorji-Bandpy, M., and H. Goodarzian. "Exergoeconomic Optimization of Gas Turbine Power Plants Operating Parameters Using Genetic Algorithms: A Case Study", Thermal Science vol. 15, pp. 43-54, 2011.

[31]. Kim, S. M, Oh S. D, Kwon Y. H., and Kwak H. Y. "Exergoeconomic Analysis of Thermal Systems", Energyvol. 23, Issue 5, pp. 393-406, 1998.

[32]. Bejan, A., Tsatsaronis G., Moran M. Thermal design and optimization, John Wiley \& Sons Inc, New York, 1996.

[33]. Lazzaretto, A and Tsatsaronis, G, "SPECO: A Systematic and General Methodology for Calculating Efficiencies and Costs in Thermal Systems", Energy, vol. ISSUE 31, 2006, pp. 1257 1289,2006 .

[34]. Obanor A. I, Dolor G. A and Egware H. O. "Exergetic Appraisal of Warri Refining Petrochemical Company Gas Turbine Power Plant", Journal of Advanced \& Applied Sciences, Vol 2, ISSN: 2289-6260, pp. 132-142, 2014.

[35]. Ighodaro 0. 0., Aburime B. A "Exergetic Appraisal of Delta IV Power Station, Ughelli", Journal of Emerging Trends in Engineering and Applied Sciences, Issue 6, Volume 2, pp. 216-218, 2011.

[36]. Ochornma, P. I. Comparative Energy and Exergy Analysis of Ihovbor Gas Power Plant With/Without Retrofitted Inlet Air Cooler, M.Eng Project (Unpublished), Departement of Mechanical Engineering, University of Benin, Edo State,. OCHORNMA PROMISE PROJECT.PDF, 2017. 